\title{
DEVELOPMENT OF A SUGAR BEET TOPPER
}

\section{Yusuf Y.R* M. Qutob* A. M. El-Beba*}

\section{ABSTRACT}

The aim of this research is to develop and evaluate a topper unit for sugarbeet suitable for Egyptian conditions. Field experiments were carried out at El-Serw Agric. Res. Station, Damietta Governorate during 2013/2014 season. The performance of the developed topper unit was evaluated at different speed ratios of 0.007, 0.0076, 0.0080 and 0.0085 under knives positions; faced $(F)$ and edged $(E)$ and flails number solo (S) and doubled (D). Different flail lengths of 15,20, 25 and $30 \mathrm{~cm}$ were tested. Over topping, under topping beets, un-topped beets, damaged beets, topping efficiency, actual field capacity, field efficiency, energy requirement and total costs were estimated. Due to increasing speed ratio increased actual field capacity and field eff. Both doubled and faced flails showed the best results under all treatments. Generally, the results recommended that topper unit should be used at speed ratio of 0.0085 with doubled-faced-flail (DFF) that recorded highest value of topping eff. (97.30\%). On the other hand, the lowest value for over topping beet (2.4\%), undertopping beets (2.8\%), un-topped beets $(2.2 \%)$ and damaged beets $(2.77 \%)$ were recorded. Hence, the best value of actual field capacity $(0.92 \mathrm{fed} / \mathrm{h})$ and field eff. $(83.4 \%)$ were recorded at speed ratio of (0.0085). Energy requirement decreased by $13.22 \%$ while total costs decreased by $78.27 \%$ comparing to manual topping costs. Flail length of $25 \mathrm{~cm}$ showed the desirable results with all treatments. Doubling and facing flails position had a high significant effect on all treatments.

\section{INTRODUCTION}

he importance of sugar beet as a source of sugar increased
in Egypt to face the local requirements of sugar. Therefore, the
area of sugar beet has increased from 1982 to 2005 by about $90 \%$. However, Egypt produce in 2005 about 1,65 million tons of sugar, while the consumption of sugar is about 2,3 million tons. Hence, only $71.7 \%$ self-sufficiency is achieved and about $28.3 \%$ has to be imported (Sugar Crops Council, 2005).

\section{*Researcher. Ag. Eng. Res. Inst. (AEnRI), Giza.}


Sugar beet is considered as a double benefit crop to the farmers, where the roots are processed for sugar production and the green leaves and tops are used for animal feeding. Mechanical sugar beet harvesters are not common in Egypt, and manual methods are exhaustive, and expensive. Kanafojski and Karwowski (1976) mentioned that beets can be topped before or after digging. Also they mentioned that the optimum cutting disc speed may be ranged in $10-13 \mathrm{~m} / \mathrm{s}$. Sugar beet topping is consumed of one feddan labor, topping of beet required $10 \mathrm{man} /$ day (Allam et al. 1988). Bulich and Brinkmann (1983) studied the problem of mechanized harvesters topping sugar beet too high or too low, or damaging they estimated that only about $60 \%$ of a sugarbeet harvest is correctly topped. O' Dogherty (1986) stated that greater precision is necessary for small beet, for example, an error of only $2.5 \mathrm{~mm}$ can result $4 \%$ overtopping and $3.5 \%$ under topping. Mechanical topping of sugar beet in Egypt is very economical and favorable as it reduces cost about $34 \%$ of manual topping. (Aly ,1998). Raininko (1990) mentioned that if the topping cut is lower than zero level (the critical section of cutting), the loss is $1.8 \mathrm{t} / \mathrm{ha}$ and the percentage of sugar in this part is $10.5 \%$, if the topping cut is lower than zero level by $1 \mathrm{~cm}$, loss is 3.3 t/ha and the percentage of sugar is $16.4 \%$ and if the cut of topping is lower than zero level by $2 \mathrm{~cm}$, loss is $3.5 \mathrm{t} / \mathrm{ha}$ and the percentage of sugar is $17.2 \%$. Cracaleanu et al., (1995) conducted using machines, labor was reduced 7 times and beet harvesting expenses decreased by over $30 \%$.

El-Sherief (1996) reported that the total cost of using tractor and harvester was reached 60.57 L.E/fed. Abou-Shieshaa (1996) excogitated topping unit, operated by using an air pressure produce from a compressor driven by PTO shaft. After that Aly (1998) developed a sugar beet topper using available power tiller. Khodeir (2002) added two rotary knives rotating in a horizontal plane to cut sugar beet foliage to Mady's harvester. Controlling of topping level was achieved by using spinner wheel fixed on the frame. Abd-Rabou (2004) constructed a leaves removing unit with a seriating knife type and beet conductor moving by automatic circle with mechanical movement Awad (2006) 
developed topping unit as the whole plant was picked up after pulling and topped by a pair of topping discs rotated opposite to each other, one of them is a smooth disc and the other is toothed. While, Mady (2001) cited that mechanical planting lead to increase the root yield. Sharobeem et al., (2003) showed that, the minimum power required was $13.16 \mathrm{~kW}$ at forward speed of $2 \mathrm{~km} / \mathrm{h}$, while the maximum power required was about $25.96 \mathrm{~kW}$ at $3.8 \mathrm{~km} / \mathrm{h}$ forward speed and the energy requirement for the developed harvester was about $22.77 \mathrm{kWh} /$ fed. Other studies report even higher energy requirements, with 11 to $16 \mathrm{~kW}$ per metre of machine width consumed by the mower at $5 \mathrm{~km} / \mathrm{h}$ (Srivastava et al. 2006). Bahnas (2006) detected that there is logical trend of the positive relation among the forward speed and both of field capacity, field efficiency and tops yield.Tayel et al (2009) recommended that topping unit can be used at speeds $(0.5 \& 7.72 \mathrm{~m} / \mathrm{s})(1 \& 16.72 \mathrm{~m} / \mathrm{s})$ treatments. It was recorded highest values for topping eff. (97.39\%), technical topping eff. (90.2\%) correct topped beet $(92.62 \%)$ at speeds $(0.5 \& 7.72 \mathrm{~m} / \mathrm{s})$. On the other hand, it was recorded lowest value for under topped beet $(2.68 \%)$, over topped beet $(4.7 \%)$ and topping losses $(77.91 \mathrm{~kg} / \mathrm{fed})$. Hence, the best value actual field capacity $(0.444 \mathrm{fed} / \mathrm{h})$ and field eff.(86.4\%) were recorded at speeds (1\& $16.72 \mathrm{~m} / \mathrm{s})$. ASABE (2011) cited a power requirement of $5.0 \mathrm{~kW} / \mathrm{m}$ of rotary cutting width. The power requirement for rotary mower-conditioners is $8.0 \mathrm{~kW} / \mathrm{m}$. The aim of this study is to develop topping unit for sugar beet foliage and evaluate the possibility of utilizing it under Egyptian conditions. The topper should be constructed by the available material on the local market to be cheaply manufactured and easily maintained locally.

\section{MATERIALS AND METHODS}

Sugar beet crop variety of Beta Poly was chosen in the present research. This variety has been grown in an area of about one feddan during the winter season of 2013/2014. Soil moisture content of $19 \%$ was determined on dry basis with the oven method at $105{ }^{\circ} \mathrm{C}$ for 24 hours.

- Tractor: Kubota tractor $30 \mathrm{~kW}(\approx 40 \mathrm{hp})$ with three hitch points $(50 \mathrm{~cm}$, height) was used. 


\section{Theoretical approach}

Rotating discs: Smooth type was used, made from austenitic stainless steel $70 \mathrm{~cm}$ diameter, $3 \mathrm{~mm}$ thickness. And to test cutting disc diameter the following equation was used:

$$
\mathrm{d}_{\mathrm{C}} \geq \mathrm{d}_{\mathrm{t}}+2 \mathrm{~s} \text {. }
$$

Where:

$\mathrm{d}_{\mathrm{C}}=$ Cutting disc diameter, $\mathrm{cm}$;

$\mathrm{d}_{\mathrm{t}}=$ Root section diameter in topping place, $\mathrm{cm}$. and

$\mathrm{s}=$ Roots admissible deflection from row center line, (left and right), $\mathrm{cm}$.

Flail length and it's number on cutting disc was determined by Srivastava's equation (1998):

$$
L_{a}=\frac{2 \pi \times V_{m}}{n_{t} \times N_{k}}
$$

Where :

$\mathrm{L}_{\mathrm{a}}=$ Flail length, $\mathrm{mm}$.

$\mathrm{V}_{\mathrm{m}}=$ Topping unit forward speed, $\mathrm{m} / \mathrm{s}$. According to Ismail et al. (1993).

Where $\mathrm{V}_{\mathrm{m}}=15 / \mathrm{N}_{\mathrm{K}}$;

$\mathrm{N}_{\mathrm{K}}=$ Cutting disc rotational speed, rpm. and $\quad \mathrm{n}_{\mathrm{t}}=$ Flail number.

A clean cut requires the foliage to be severed above the critical speed, since significantly less foliage deflection occurs. By equating cutting forces with the expected rigidity of the plant, Persson (1987) provides an equation for estimating critical speed,

$$
v_{k}=\sqrt{d_{s} \frac{F_{x}-F_{b}}{m_{p}}}\left(1+\frac{z_{c g}}{r_{g}^{2}}\right)
$$

where: $v_{k}=$ critical knife velocity, $\mathrm{m} / \mathrm{s}$;

$d_{s}=$ stalk diameter, $\mathrm{m}$; $F_{x}=$ cutting force, $\mathrm{N}$;

$F_{b}=$ bending resistance of stump, $\mathrm{N}$; $z_{c g}=$ height of center of gravity of cut plant, $\mathrm{m}$; $r_{g}=$ radius of gyration of cut portion of plant, $\mathrm{m}$ and $m_{p}=$ mass of cut portion of plant, $\mathrm{kg}$ According to (Srivastava et al. 2006), a simple approximation to this equation can be obtained by assuming that $r_{g}=z_{c g}$ 
Centrifugal force: A force, arising from the flails' inertia, which appears to act on a body rotating in a circular path and is directed away from the centre around which the body is rotating. (Fig. 1)

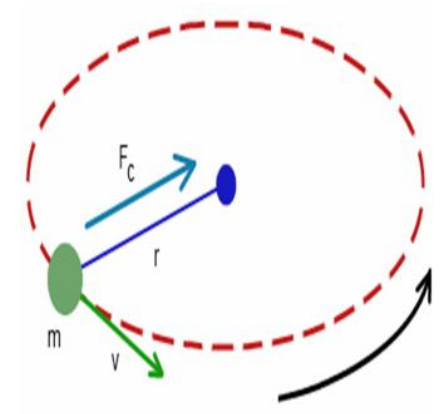

Fig.1: Factors affecting positive centrifugal force

$F_{c}=\frac{m v^{2}}{r}$

$F_{c}=\frac{m(n 2 \pi r / 60)^{2}}{r}$

Where, Fc: the centrifugal force, N. ;

m: mass, kg.;

$\mathrm{v}$ : velocity, $\mathrm{m} / \mathrm{s} ; \mathrm{r}$ : radius, $\mathrm{m}$. and

$\mathrm{n}$ : revolution per minute, rpm

\section{Mower specifications before modifications}

A rotary mower for forage with two discs was modified to operate as a sugar beet topper before harvesting sugar beet. Mower is composed of two discs spin quickly through a set of gears and the two discs have three knives made of steel. In horizontal plain, three consequence flails at angle of 120 degree apart, (Fig. 2). The mower working width $150 \mathrm{~cm}$ under $22 \mathrm{~kW}$ power needed (according to equations 4 and 5). The knives are hinged so that they move to the outside by centrifugal force caused by rotation and inside when the motion stops, or when collide with a solid part. In case of both sides of the knife erosion occurred. Table 1 shows the used mower specifications. 
Table 1: Mower used specifications

\begin{tabular}{|l|c|l|c|}
\hline \multicolumn{1}{|c|}{ Items } & Feature & \multicolumn{1}{c|}{ Items } & Feature \\
\hline $\begin{array}{l}\text { Cutting width, } \\
\mathrm{cm}\end{array}$ & 150 & Drive & $\begin{array}{c}\text { Hex shaft from } \\
\text { gearbox }\end{array}$ \\
\hline Weight, kg & 500 & Gearcase drive & $\begin{array}{c}\text { 4V "HB" section } \\
\text { belts }\end{array}$ \\
\hline $\begin{array}{l}\text { Cutting angle, } \\
\text { degree }\end{array}$ & $0-6$ & $\begin{array}{l}\text { Minimum PTO: } \\
\text { hp, }(\mathrm{kW})\end{array}$ & $30(22)$ \\
\hline Number of discs & 2 & PTO speed, rpm & 540 \\
\hline $\begin{array}{l}\text { Number of } \\
\text { knives }\end{array}$ & $6(3$ per disc) & Hydraulics & $\begin{array}{l}\text { Single-acting } \\
\text { remote valve }\end{array}$ \\
\hline Disc speed, rpm & 2200 & 3-point hitch & \\
\hline Knives & Swingaway, reversible & & \\
\hline
\end{tabular}

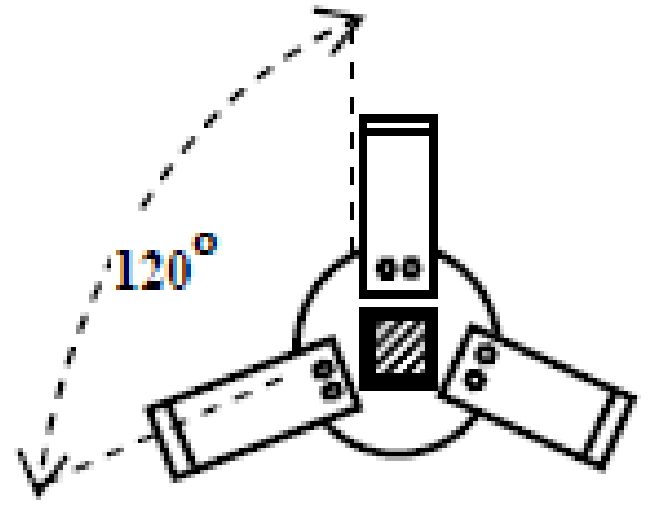

Fig. 2: The flails distribution on a disc

\section{Mower specifications after modifications (Topper design)}

The three horizontal knives in each disc were replaced with three rubber flails fixed in a vertical position (Fig. 3) by a steel flanges for each. The three flanges and the flails were the same to keep the disc balance and stability and to prevent vibration due to the different centrifugal forces. The topper horizontal position was adjusted at the optimum position by a flywheel.

Rubber flails: Rubber flails of $7.0 \mathrm{~cm}$ width and $2.0 \mathrm{~cm}$ thickness with different lengths of 15,20,25 and $30 \mathrm{~cm}$ lengths were typically weighed. Two holes in each flail were done to be fixed on the flange mounted on the disc. Fig. 3. 


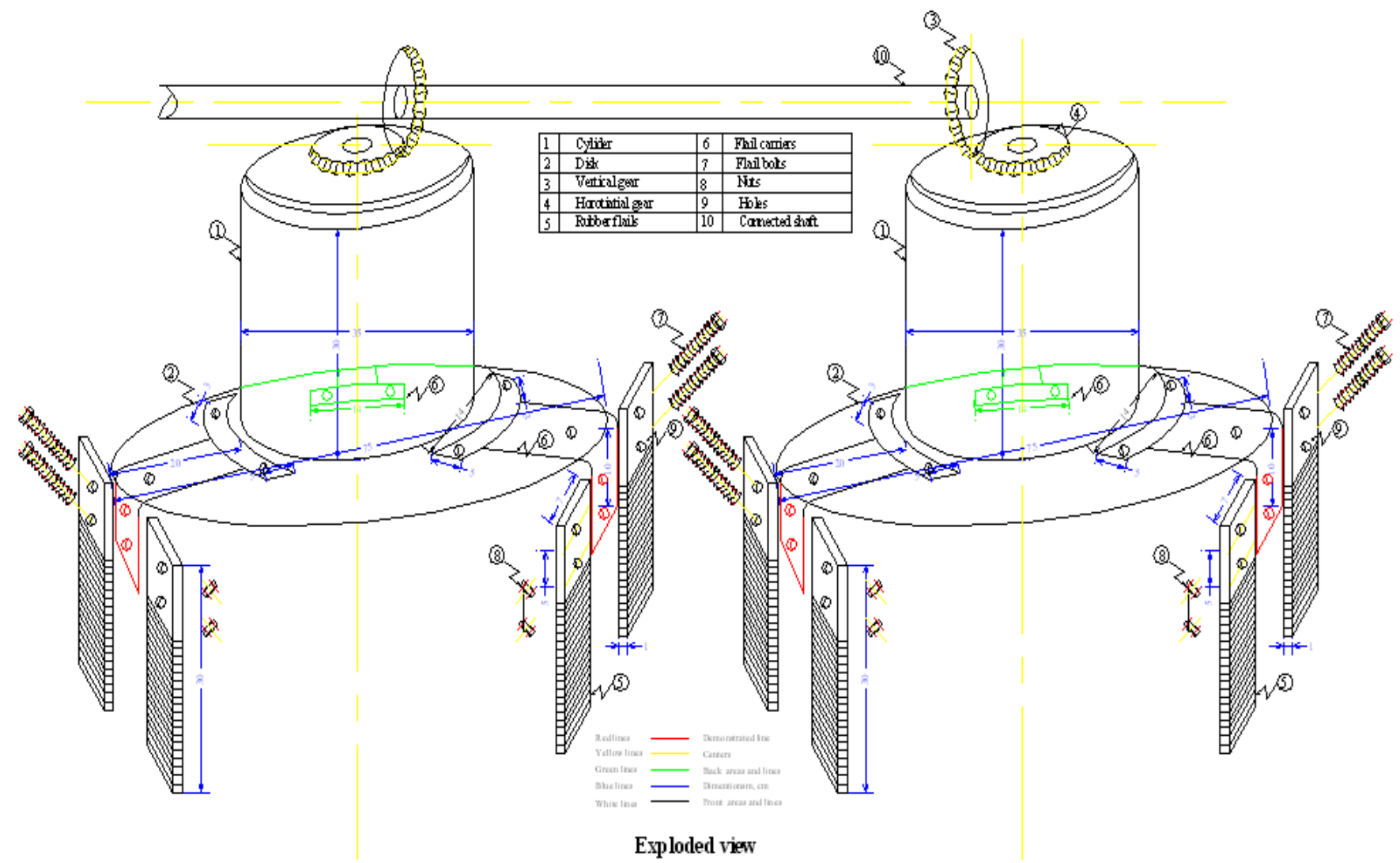

Fig. 3: A schematic diagram of the modified topper 
Rake angle ( $\boldsymbol{\alpha})$ : Is a parameter used in various cutting and machining processes, describing the angle of the cutting face relative to the direction of the motion. There are two rake angles, namely the back rake angle and side rake angle, both of which help to guide chip flow. The rake angle changed by changing the centrifugal force, according to changing disc rotating speed. (Fig. 4).

\begin{tabular}{|c|l|}
\hline $\mathrm{P}$ & $\begin{array}{l}\text { Position under } \\
\text { different peripheral } \\
\text { speed }\end{array}$ \\
\hline$\alpha$ & $\begin{array}{l}\text { Flail cut angle under } \\
\text { different peripheral } \\
\text { speed }\end{array}$ \\
\hline $\mathrm{L}$ & $\begin{array}{l}\text { Length under } \\
\text { different peripheral } \\
\text { speed }\end{array}$ \\
\hline
\end{tabular}

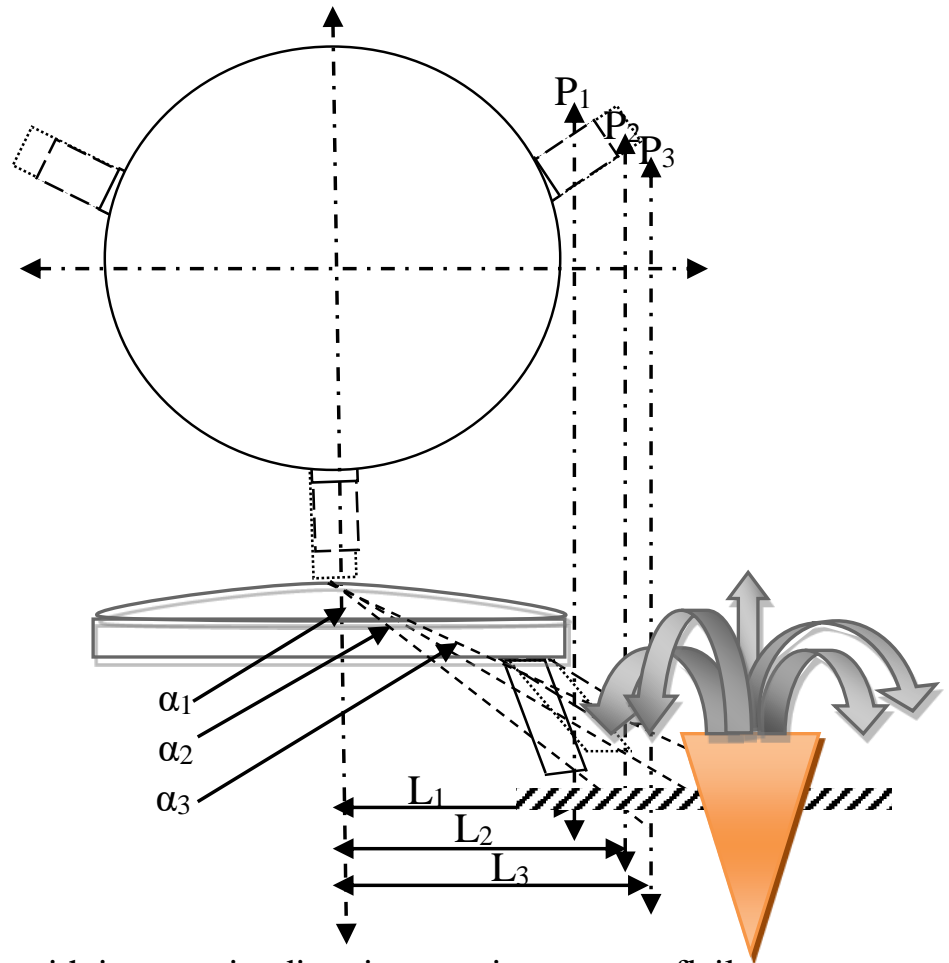

Fig. 4: Rotating mower discs with in opposite direction rotating counter flails.

\section{The used rubber flails}

A rubber flail is chosen so that in the unloaded condition the internal tensile forces acting on each layer of fabric are uniform. Fig. 5.

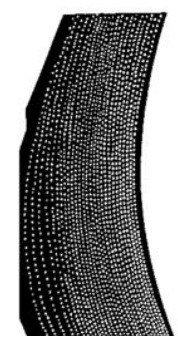

Unloaded cross section

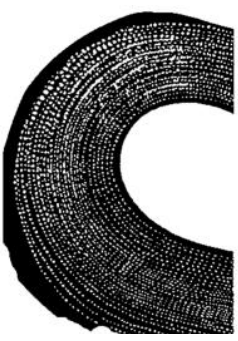

Loaded cross section

Fig. 5: A Photo of cross section of the used rubber flail in faced position 
According to the previous equations estimation, the speed ratio, flail length, flail position and flail numbers were chosen and tested with different important measurements.

The experimental design: The experiments were carried out in a rectangular shape area of about one feddan in a split-split plot design of about $95 \mathrm{~m}$ long and $45 \mathrm{~m}$ wide. Soil samples were taken from a depth level of $10-25 \mathrm{~cm}$. The mechanical analysis of the soil was conducted in the Lands and Soil Research Institute, El-Serw Agric. Res. Station. The experimental tests done at clay soil texture and the soil specification are in table (1).

Table (2): Soil physical analysis :-

\begin{tabular}{|c|c|c|c|c|}
\hline \multicolumn{3}{|c|}{ Soil composition \% } & \multirow{2}{*}{ Soil texture } \\
\hline \multirow{2}{*}{ Clay, $\%$} & \multirow{2}{*}{ Silt, \% } & \multicolumn{2}{|c|}{ Sand, \% } & Coarse \\
\cline { 3 - 4 } & 20 & 4.2 & 27.8 & Clay \\
\hline 48 & 20 &
\end{tabular}

Test factors: According to equations 1,2 and 3 disc diameter, flail length and peripheral disc speed the following parameters were determined.

1- Speed ratio (SR): The measure of how a machine affects speed is called the speed ratio. It is calculated by dividing the input speed (topper forward speed) by the output speed (Disc peripheral speed).

* Topper forward speed: $0.22,0.36,0.53$ and $0.67 \mathrm{~m} / \mathrm{s}$.

* Disc peripheral speeds:31.4, 47.1, 62.8 and $78.5 \mathrm{~m} / \mathrm{s}$.

It means that the following speed ratios were used: $0.007,0.0076$, 0.0080 and 0.0085

2- Flail length, $\mathrm{cm}(15,20,25$ and $30 \mathrm{~cm})$

3- Flail position system, edged position (E) and faced-position (F)

4- Flail numbers, solo (S) and doubled (D), Fig. 6.

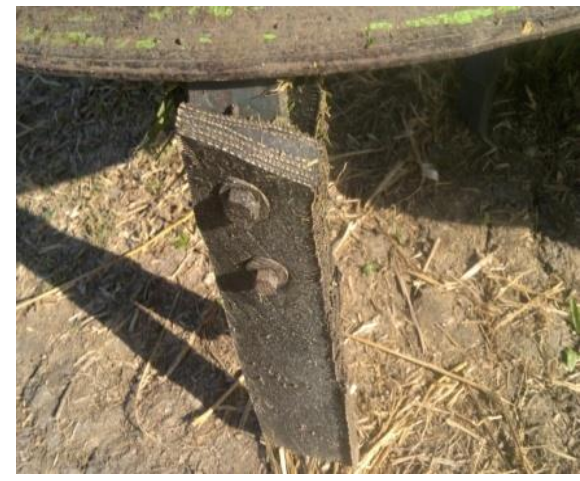

A photo of Solo-Edged-Flail (SEF)

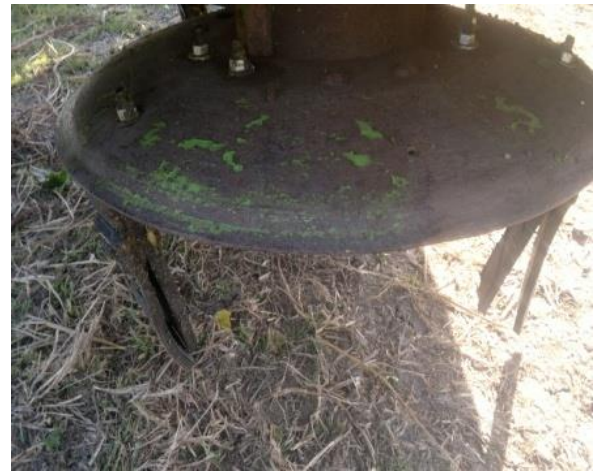

A photo of Doubled-Edged-Flail (DEF)

Fig. 6: Shows solo-edged-flail and doubled-edged-flail 


\section{Measurements:}

1- Beet crop quality: over topped, under topped, un-topped beet and topping efficiency were assessed in a percent as indicator of the topping unit performance.

Topping losses: During the experimental work, the performance of topper assessed by taking randomly selected $10 \mathrm{~m}$ of work length, lifting the beet, manually and collecting the tops. So under or overtopped and damaged should be estimated easily. The percentage of the items, which are used to control topper performance can be calculated as the following (Richey et al., 1961).

Over topped beet $=\frac{\text { No. of over topped beet }}{\text { Total No. of topped beet }} \times 100$

Under topped beet $=\frac{\text { No. of under topped beet }}{\text { Total No. of topped beet }} \times 100$

Untopped beet $=\frac{\text { No. of untopped beet }}{\text { Total No. of topped beet }+ \text { No of untopped beet }} \times 100$

Damaged beet $=\frac{\text { No. of damaged beet }}{\text { Total No. of beet }} \times 100$

- Total damage percentage, \% (Dc) was calculated by using the following equation:

$$
D_{c}=\frac{N_{d}}{N_{s}+N_{d}} \times 100
$$

Where:

$\mathrm{D}_{\mathrm{c}}=$ total damaged percentage, $\%$;

$\mathrm{N}_{\mathrm{d}}=$ mass of the damaged sugar beet harvested from the experimental unit, $\mathrm{kg}$ and

$\mathrm{N}_{\mathrm{s}}=$ mass of the undamaged sugar beet harvested from experimental unit, $\mathrm{kg}$.

Topping efficiency $(\%)=$ Topped beet No./Total beet No.

- Actual field capacity: Actual field capacity was the actual average time consumed during topping operation (lost time + productive time). It can be determined from the following equation: 


$$
F . C_{a c t}=\frac{60}{T u+T i} \mathrm{fed} / \mathrm{h}
$$

Where:

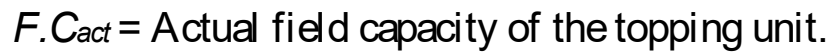

$T_{u}=$ Utilization time per feddan in minutes.

$T_{i}=$ Summation of lost time per feddan in minutes.

\section{- Field efficiency:}

Field efficiency is cal culated by using the values of the theoretical field capacity and effective field capacity rates as:

$$
\eta_{f}=\frac{\text { actual field capacity }}{\text { theoritical field capacity }} \times 100
$$

Where:

$\eta_{f}=$ Field efficiency, $\%$.

\section{-Energy requirement:}

To estimate the engine power during topping operation, the decrease in fuel level in fuel tank accurately measuring immediately after each treatment. The following formula was used t o estimate the engine power (Hunt, 1983):

$E P$

$=\left[F . C\left(\frac{1}{3600}\right) \times \rho E \times \operatorname{LCV} \times 427 \times \eta T H B \times \eta m \times \frac{1}{75} \times \frac{1}{1.36}\right], k W$

Where:-

$E P=$ engine power, $\mathrm{kW}$;

F.C = Fuel consumption, $(I / \mathrm{h})$.

$\rho E=$ Density of fuel, $(\mathrm{kg} / \mathrm{l})$, (for Gas oil $=0.85)$.

L.C.V = Cal orific value of fuel, $(11.000 \mathrm{k} . \mathrm{cal} / \mathrm{kg})$.

$\eta_{T H B}=$ Thermal efficiency of the engine, ( $35 \%$ for Diesel engine).

$427=$ Thermo-mechani cal equival ent, (kg.m/k.Cal).

$\eta_{m}=$ Mechanical efficiency of the engine, (80\% for Diesel engines).

So, the energy can be cal culated as following:

$$
\text { Energy requirement }=\frac{\text { engine power }(\mathrm{kW})}{\text { field capacity }(\mathrm{fed} / \mathrm{h})}
$$

- Costs: The hourly cost for topping unit was determined using the following equation, Hunt, (1983)

Hourly cost $=\mathrm{P} / \mathrm{H}(1 / \mathrm{A}+\mathrm{I} / 2+\mathrm{T}+\mathrm{R})+(0.9 \mathrm{~W} . \mathrm{S} . \mathrm{F})+\mathrm{M} / 144, . \mathrm{E} \cdot \mathrm{h}$ 
Where:

$\mathrm{P}=$ price of machine, L.E, $\quad \mathrm{H}=$ yearly working hours, h/year,

$\mathrm{A}=$ life expected of machine, year, $\mathrm{I}=$ interest rate / year,

$\mathrm{T}=$ taxes, over heads ratio, $\quad \mathrm{R}=$ repairs and maintenance ration,

$0.9=$ factor accounting for lubrication $\quad \mathrm{W}=$ power, $\mathrm{hp}$,

$\mathrm{S}=$ specific fuel consumption (L/hp.h), $\quad \mathrm{F}=$ fuel price, L.E. / L,

$\mathrm{M} / 144$ = monthly wage ratio, L.E,

Generally, total cost of topping operation, L.E./fed was assumed according to the formal recent prices for hiring tractors and machines from Agricultural Engineering Stations and the wages of hired operators for manual beet topping of $30 \mathrm{LE} /$ operator. One sugar beet feddan needs not less than 25-30 operators according to the quality of the crop.

The operating cost for topping unit was calculated by the following equation:

$$
\text { Operating cost, } L E / \text { fed }=\frac{\text { machine cost }, L E / h}{\text { actual field capacity, fed } / h} \ldots \ldots .
$$

\section{- Measuring instruments:}

An electric oven, a hand peeler, a balance (accuracy of $1.0 \mathrm{~g}$ ), a stopwatch for consuming time through a travel of 10 meters length, a steel tape, a ruler, a tachometer for measuring the rotational speed.

- The statistical analysis: The experiments were arranged in split-split plot design with three replicates and analyzed by using Minitab software (Regression analysis and ANOVA).

\section{RESULTS AND DISCUSSION}

\section{Over topping beet:}

Figs. (7, 8, 9 and 10) show the effect of speed ratio and flail length (15, 20, 25 and $30 \mathrm{~cm}$ ), flail number (solo, S and doubled, D) and flail position (faced, F and edged, E) on over topping beet. Data revealed that increasing speed ratio resulted in decreasing the overtopping beets, $\%$. Increasing speed ratio from 0.007 to 0.008 resulted in decreasing the overtopping beets from 3.15 to $2.50 \%$ under doubled-faced-flail (DFF) length of $25 \mathrm{~cm}$. In the same way the doubled-faced-flail (DFF) showed a decrease in overtopping beets more than the solo-faced-flail (SFF). Overtopping beets decreased from 3.95 and 3.65 to 2.4 and $2.5 \%$ for 
DFF and SFF, respectively under speed ratio of 0.0085 and flail length of $30 \mathrm{~cm}$. Speed ratio of 0.0085 gave approximately relative results with speed ratio of 0.008 but there was a noticed vibration with speed ratio of 0.0085. Flail length effect on overtopping was ordered as $25<30<20<15$ $\mathrm{cm}$. Flail length of $25 \mathrm{~cm}$ showed the optimum results under the different parameters. Also, DFF in all treatments gave the lowest overtopping beets. These results may be because the DFF caused a sudden impact more than the SFF with the wide section of the flail which resulted in little overtopping. It was found that the DEF showed higher values than DFF, $R^{2}=0.7572$. Data analyzed showed a significant differences $(\mathrm{p}<0.01)$ among all parameters.

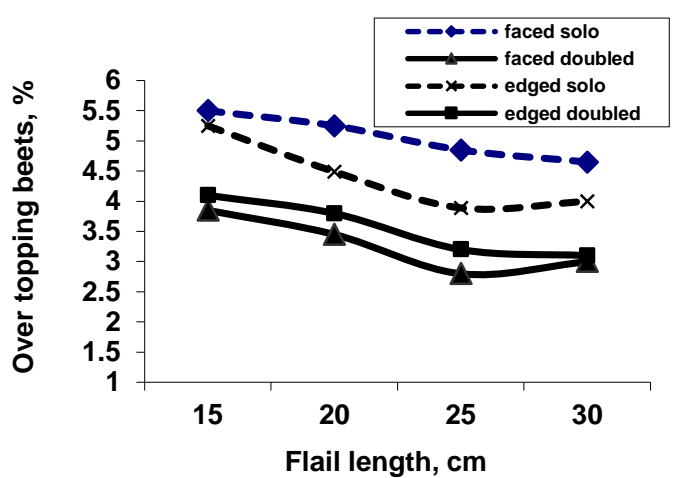

Fig. 7: Effect of flail (length, number and position) on over topp beet under speed ratio of 0.007 .

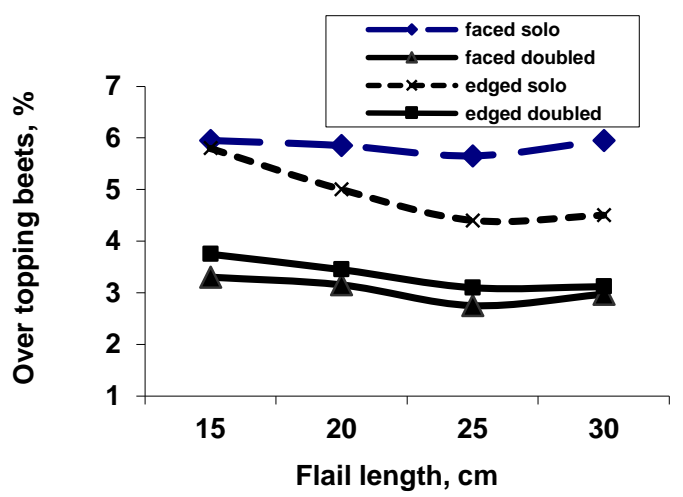

Fig. 9: Effect of flail (length, number and position) on over topp beet under speed ratio of 0.008 .

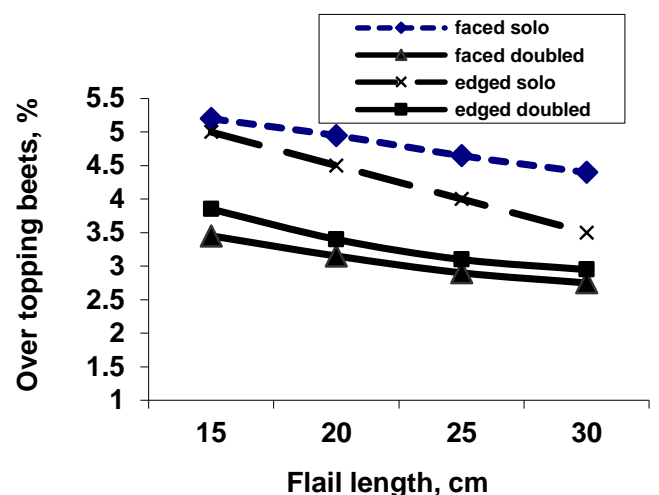

Fig. 8: Effect of flail (length, number and position) on over topp beet under speed ratio of 0.0076 .

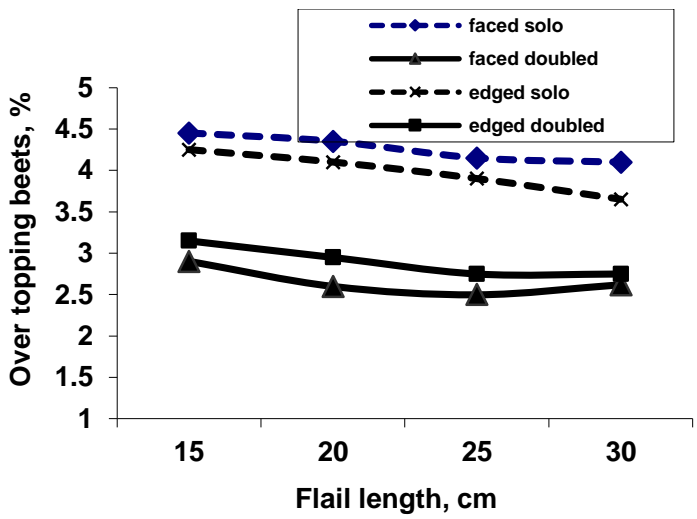

Fig. 10: Effect of flail (length, number and position) on overtopped beet under speed ratio of $\mathbf{0 . 0 0 8 5}$. 


\section{Under topping beet.}

The Effect of speed ratio and flail length $(15,20,25$ and $30 \mathrm{~cm})$, flail number (solo, S and doubled, D) and flail position(faced, F and edged, E) on under topping beet is shown on figs. $(11,12,13$ and 14). Data revealed that increasing speed ratio resulted in decreasing the undertopping beets, \%. Increasing speed ratio from 0.007 to 0.008 resulted in decreasing the undertopping beets from 3.28 to $2.80 \%$ under doubled-faced-flail (DFF) length of $25 \mathrm{~cm}$. Similarly, DFF showed a decrease in undertopping beets more than the solo-faced-flail (SFF). Undrtopping beets decreased from 4.20 and 4.88 to 2.8 and $2.4 \%$ for DFF and SFF, respectively under speed ratio of 0.008 and flail length of $25 \mathrm{~cm}$. Speed ratio of 0.0085 gave relatively similar results with speed ratio of 0.008 but there was a high vibration and the flails began to take a horizontal position specially with flail length of $30 \mathrm{~cm}$ according to the centrifugal force with speed ratio of 0.0085 . Flail length effect on undertopping was ordered as $25<30<20<15 \mathrm{~cm}$. Flail length of $25 \mathrm{~cm}$ showed the optimum results under the different parameters. Also, DFF in all treatments gave the lowest undertopping beets more than solo-edgedflail (SEF), $\mathrm{R}^{2}=0.8252$. These results may be because the DFF caused a sudden impact with the wide section of the flail which resulted in little undertopping. Data analyzed showed a significant differences $(p<0.01)$ among all parameters.

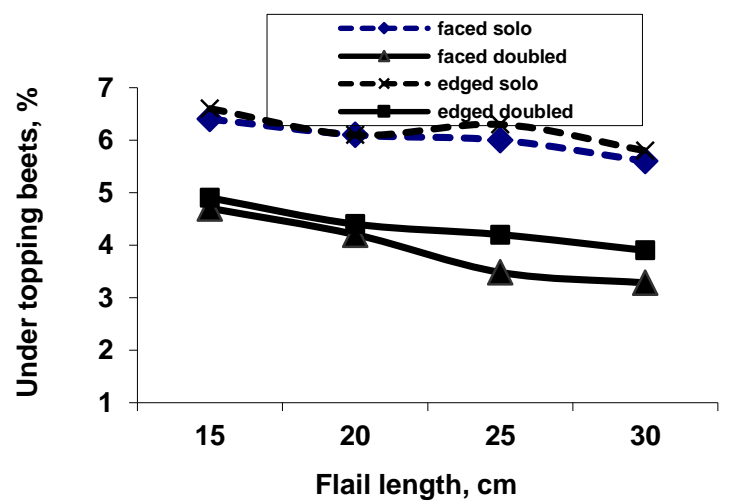

Fig. 11: Effect of flail (length, number and position) on under-topping beet under speed ratio of 0.007 .

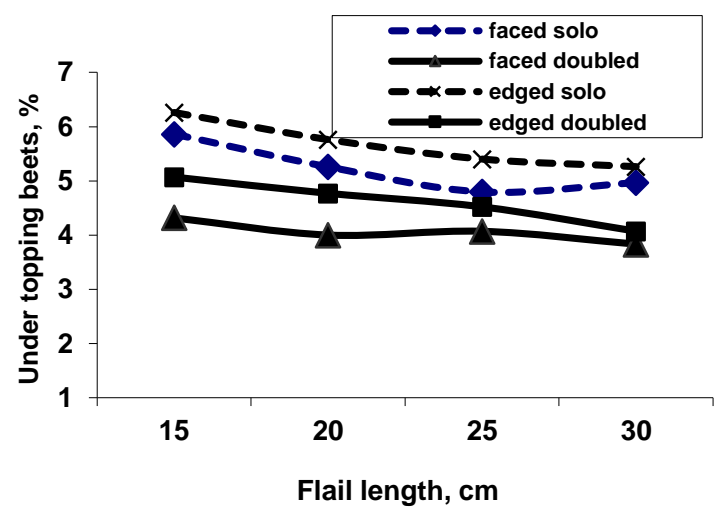

Fig. 12: Effect of flail (length, number and position) on undertopping beet under speed ratio of 0.0076 . 


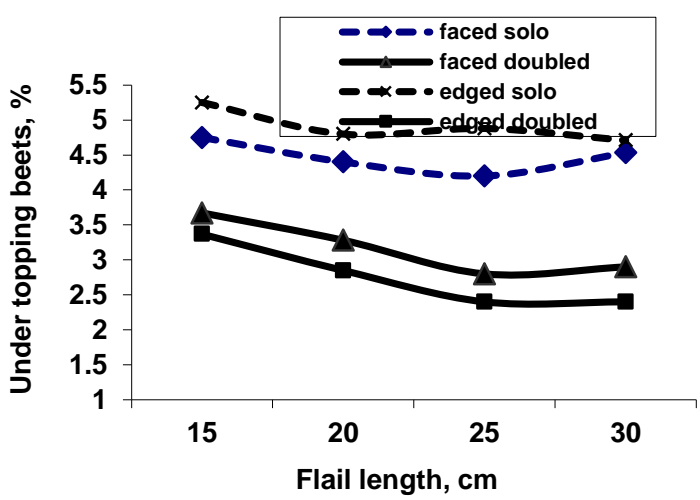

Fig. 13: Effect of flail (length, number and position) on under- topping beet under speed ratio of 0.008 .

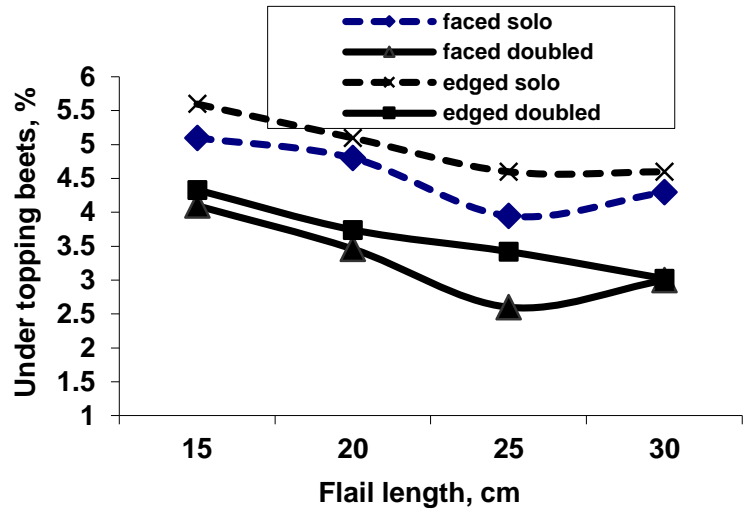

Fig. 14: Effect of flail (length, number and position) on under-topping beet under speed ratio of 0.0085 .

\section{Un-topped beet.}

The Effect of speed ratio and flail length $(15,20,25$ and $30 \mathrm{~cm})$, flail number (solo, S and doubled, D) and flail position(faced, F and edged, E) on un-topped beet is shown on figs. (15, 16, 17 and 18). Data indicated that increasing speed ratio resulted in decreasing the un-topped beets, $\%$. Increasing speed ratio from 0.007 to 0.0085 resulted in decreasing the untopped beets from 3.0 to $1.75 \%$ under DFF with length of $25 \mathrm{~cm}$. Similarly, DFF showed a decrease in un-topped beets more than the SFF. Un-topped beets decreased from 3.35 and 3.65 to 1.75 and $2.2 \%$ for DFF and SFF, respectively under speed ratio of 0.0085 and flail length of 25 $\mathrm{cm}$. Speed ratios of 0.0076 and 0.008 gave relatively similar results with speed ratio of 0.008 but discs centrifugal force resulted in more vibration specially with SEF and the flails began to take a horizontal position specially with flail length of $30 \mathrm{~cm}$ with speed ratio of 0.0085 . Speed ratio of 0.007 gave the highest values of un-topped beets. Flail length effect on un-topped was ordered as $25<30<20<15 \mathrm{~cm}$. Flail length of 25 $\mathrm{cm}$ showed the optimum results under the different parameters. Also, DFF in all treatments gave the lowest un-topped beets more than SEF, $\mathrm{R}^{2}$ $=0.8652$. These results may be because the DFF caused a sudden impact with the wide section of the flail which resulted in little un-topped beets. Data analyzed showed a significant differences $(p<0.01)$ among all parameters. 


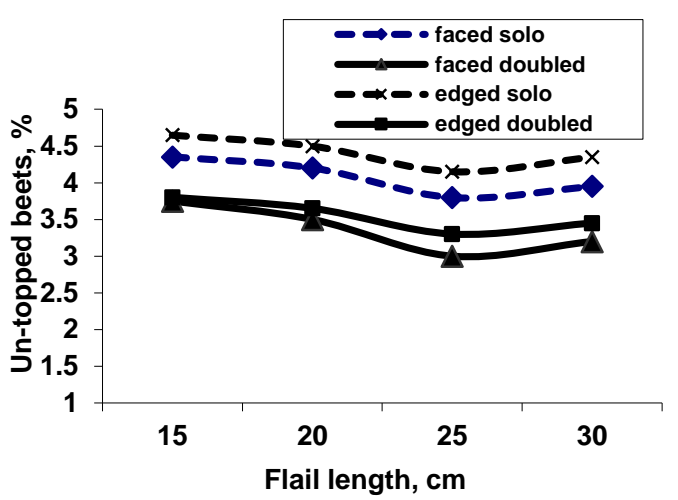

Fig.15: Effect of flail (length, number and position) on un-topped beet under speed ratio of 0.007 .

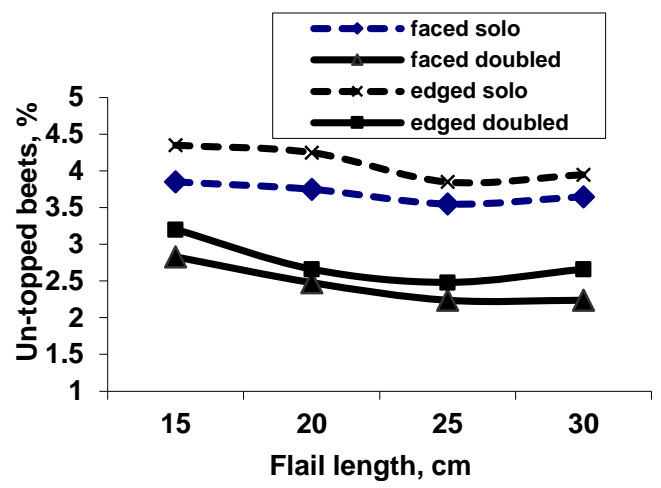

Fig. 17: Effect of flail (length, number and position) on un-topped beet under speed ratio of 0.008 .

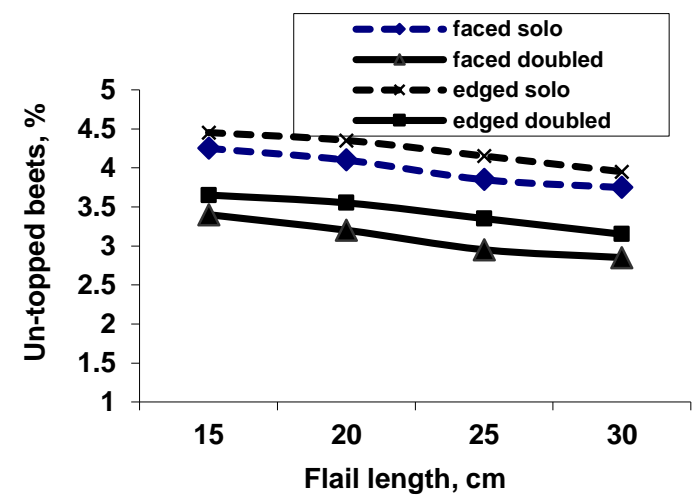

Fig. 16: Effect of flail (length, number and position) on un-topped beet under speed ratio of 0.0076 .

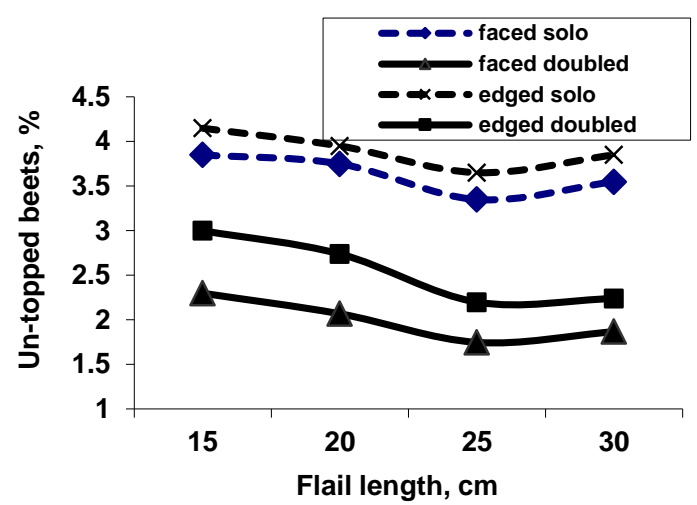

Fig. 18: Effect of flail (length, number and position) on un-topped beet under speed ratio of 0.0085 .

\section{Effect of speed ratio and flail (length, number and position) on}

\section{topping efficiency.}

Figs (19, 20, 21 and 22) illustrated the effect of speed ratio and flail length (15, 20, 25 and $30 \mathrm{~cm}$ ), flail number (solo, $\mathrm{S}$ and doubled, D) and flail position (faced, F and edged, E) on topping efficiency beet. Data indicated that increasing speed ratio resulted in increasing the topping efficiency beets, $\%$. Increasing speed ratio from 0.007 to 0.0085 resulted in decreasing the topping efficiency beets from 97.50 to $98.10 \%$ under DFF with length of $30 \mathrm{~cm}$. Similarly, DFF showed an increase in topping efficiency beets more than the SFF and this may be because of the centrifugal force was obvious with solo-flail specially with the edged 
flail position. Topping efficiency beets increased from 96.45 and 95.37 to 97.5 and $97.30 \%$ for DFF and SFF, respectively under speed ratio of 0.0085 and flail length of $25 \mathrm{~cm}$. Speed ratios of 0.0076 and 0.008 gave relatively similar results with speed ratio of 0.008 . It was noticed that the flails began to take a horizontal position specially with edged-flail length of $30 \mathrm{~cm}$ with speed ratio of 0.0085 . Speed ratio of 0.008 gave the highest values of topping efficiency, $R^{2}=951$. Flail length effect on topping efficiency was ordered as $25<30<20<15 \mathrm{~cm}$. Also, DFF in all treatments gave the highest topping efficiency beets more than SEF. Data analyzed showed a significant differences $(\mathrm{p}<0.01)$ among all parameters.

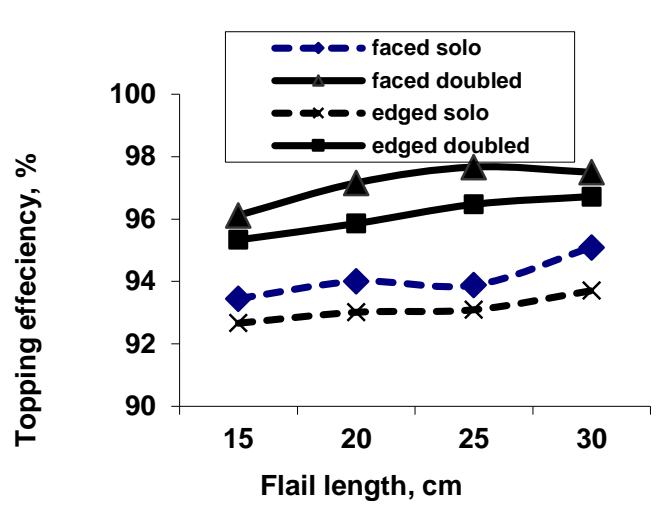

Fig. 19: Effect of flail (length, number and position) on topping effeciency under speed ratio of 0.007 .

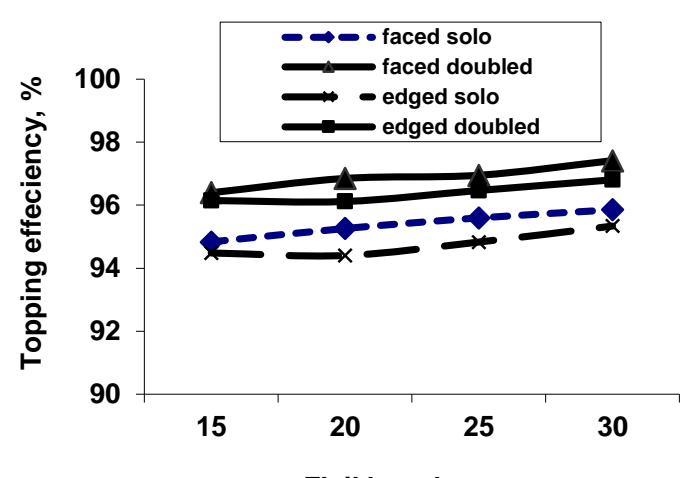

Flail length, $\mathrm{cm}$

Fig. 21: Effect of flail (length, number and position) on topping effeciency under speed ratio of 0.008 .

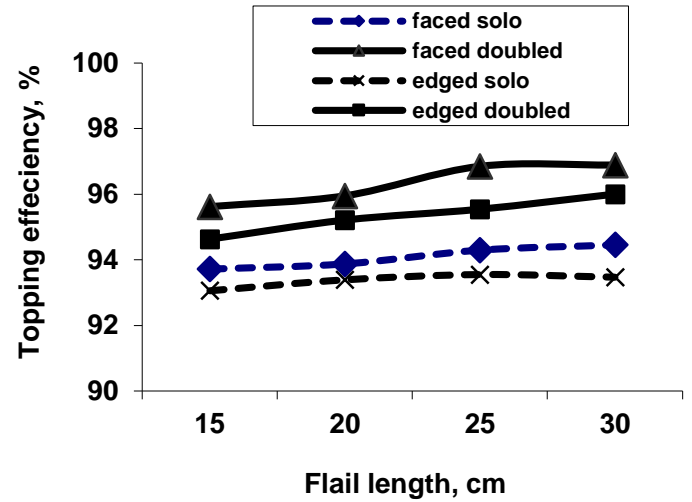

Fig. 20: Effect of flail (length, number and position) on topping effeciency under speed ratio of 0.0076 .

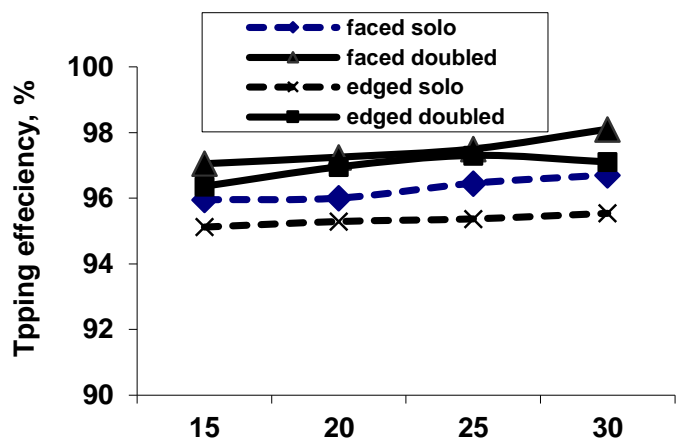

Flail length, cm

Fig. 22: Effect of flail (length, number and position) on topping effeciency under speed ratio of 0.0085 . 


\section{Damaged beets.}

It was noticed that the most damaged beets assumed in this trial was because of tractor wheels and less damaged beet values was because of the developed topper. Beet planting method (manually) and the unsystemized distance between rows caused that the tractor had to pass over some beets which resulted in the obtained results. The Effect of speed ratio and flail length $(15,20,25$ and $30 \mathrm{~cm}$ ), flail number (solo, $\mathrm{S}$ and doubled, D) and flail position (faced, F and edged, E) on damaged beet is shown on figs. (23, 24, 25 and 26). Data indicated that increasing speed ratio resulted in increasing the damaged beets, $\%$. Increasing speed ratio from 0.007 to 0.0085 resulted in increasing the damaged beets from 2.77 to $3.50 \%$ under SFF with length of $25 \mathrm{~cm}$. Similarly, DEF showed an increase in damaged beets more than the SFF because of disc centrifugal force. Damaged beets increased from 2.72 and 2.95 to 3.50 and $3.95 \%$ for DFF and SFF, respectively $\left(\mathrm{R}^{2}=0.7366\right)$ under speed ratio of 0.0085 and flail length of $25 \mathrm{~cm}$. Speed ratio of 0.007 gave the lowest values of damaged beets. Flail length effect on damaged was ordered as $25>30>20>15 \mathrm{~cm}$. The lowest speed ratio according to the minimum forward speed results in decreasing the damaged beets because the tractor moved slowly and the operator could control the direction and could prevent passing on the beets. These results may be because the tractor wheels moved between rows which resulted in little damaged beets. Data analyzed showed a significant differences $(\mathrm{p}<0.01)$ among all

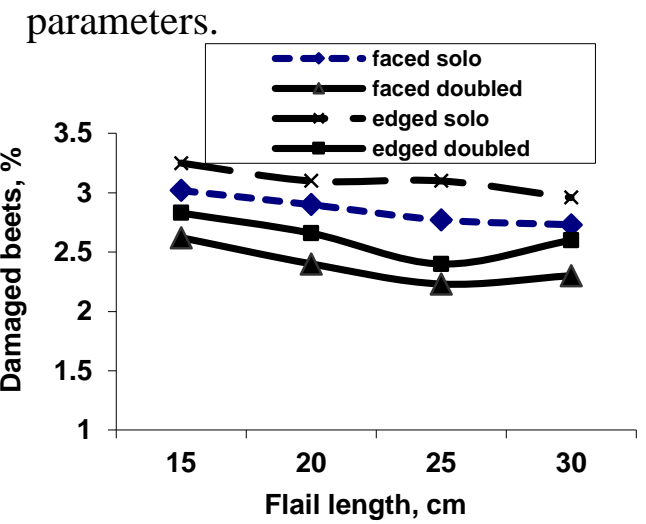

Fig. 23: Effect of flail (length, number and position) on damaged beet under speed ratio of 0.007 .

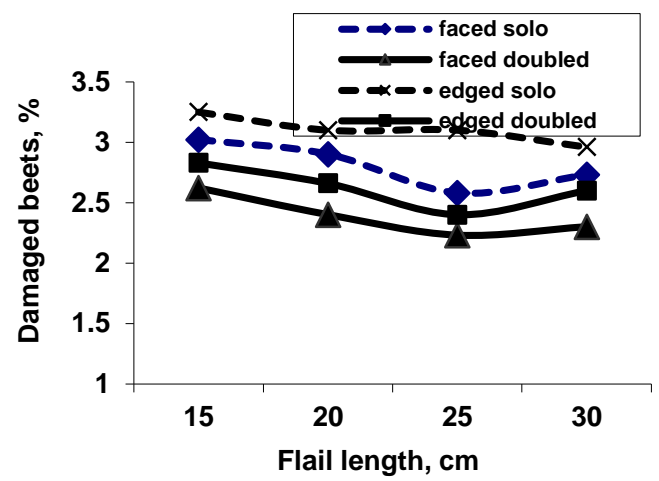

Fig. 24: Effect of flail (length, number and position) on damaged beet under speed ratio of 0.0076 . 


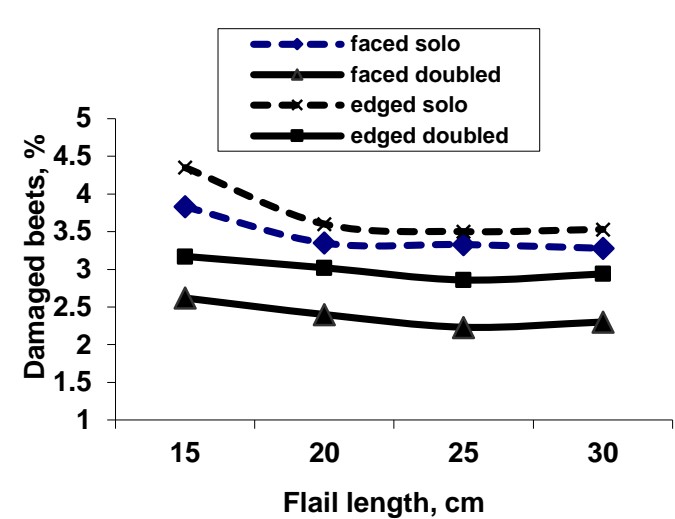

Fig. 25: Effect of flail (length, number and position) on damaged beet under speed ratio of 0.008 .

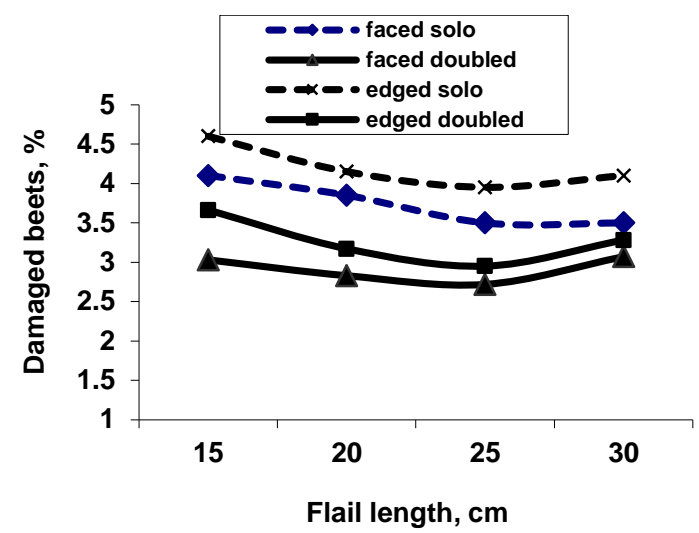

Fig. 26: Effect of flail (length, number and position) on damaged beet under speed ratio of 0.0085 .

\section{Energy requirements and total costs:}

From equations 13 and 14, it was obvious that, increasing speed ratio increased power values but decreased energy requirements. The increase in required power by increasing speed ratio is due to increasing in fuel consumption due to increase in load. While the decrease in energy requirements by increasing speed ratio could be due to the high increase in field capacity compared with the increase in the required power. According to Fig. 27, increasing speed ratio from 0.007 to 0.0085 , field capacity increased from $0.29 \mathrm{fed} / \mathrm{h}$ to $0.92 \mathrm{fed} / \mathrm{h}$ ). Field efficiency increased from $80 \%$ and $83.4 \%$ ) at doubled-faced-flails (DFF), while energy requirement decreased by $13.22 \%$ under the same conditions. According to the actual recent prices (equations 15 and 16), one feddan cost about 163 LE. The decrease in cost by increasing the speed ratio from 0.007 to 0.0085 was attributed to the increase in field capacity, while the increase in cost by increasing speed ratio up to 0.0085 was due to the increase in total losses cost.

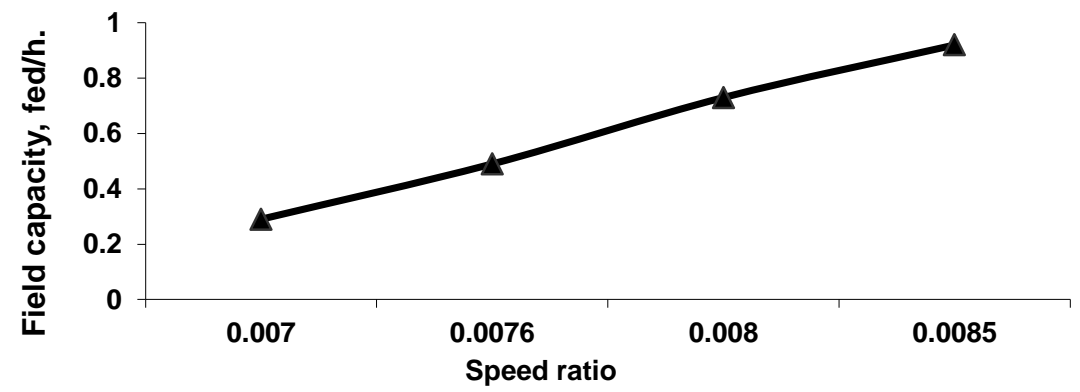

Fig. 27: Effect of speed ratio and faced-doubled-flails on actual field capacity(fed/h) under flail length of $25 \mathrm{~cm}$. 


\section{SUMMARY AND CONCLUSION}

The main purposes of this study were to develop and evaluate suitable unit for topping sugar beet crop. The conclusions of this study can be summarized as follows:

* Increasing speed ratio (topper forward speed dividing by topping disc peripheral speed) increased topping eff., field capacity and correct topped beet and also, damaged beets increased while overtopping, undertopping and un-topped beets decreased at all treatments under the same conditions.

* Then, the statistical analysis cleared that using both doubled-facedflails (DFF) showed the most desirable values for all treatments more than the solo-edged-flails (SEF). On the other hand in all treatments the faced flails showed desirable values more than the edged flails.

* The length of chopped foliage can be varied by varying the speed of the cutting unit, the number of cutting flails or by adjusting the length of the cutting flail. The forage chopper will also enhance silage making for intensive zero grazing livestock farming and management.

* This study recommended developing the topper unit to be multi-units with a technique for collecting the foliage after topping. This will help to increase the field capacity and topper efficiency.

\section{REFERENCES}

Abd-Rabou.A.F., (2004). Manufacturing a small machine to suit harvesting sugar beet under Egyptian conditions. Ph. D., Thesis. Agric. Mech. Dept., Fac. Agric., Kafr El - Sheikh. Tanta Univ.

Abou-shieshaa, R. R., (1996). A study on harvesting mechanization of sugar beet. Ph.D., Thesis. Agric. Mech. Dept., Fac. Agric. Kafr El-Sheikh. Tanta Univ.

Allam, A. I., A. M. Nour., and M. A. Farag., (1988). Prospective of sugar beet mechanical growing. Agric. Res. Review., Agric. Res. Center., Giza., Egypt, 66 (3): 537-543. 
Aly, A.H., (1998). Design and development of a sugar beet topper. Ph.D., Thesis. Agric. Mech . Dept., Fac. Agric., Ain Shams Univ.

ASABE D497.7.( 2011). Agricultural Machinery Management Data. ASABE D497.7.

Awad, M.A., 2006. Developing of a pulling out mechanism for harvesting sugar beet crop. Ph.D. Thesis. Agric. Eng. Dept., Fac. Agric., Mansoura Univ.

Bahnas, O.T., (2006). The mechanical sugar beet harvest requirements in the reclaimed lands. Misr. J. Agric. Eng., 23(4): $909-928$.

Bulich-C; and W. Brinkmann, (1983). Harvesting losses in sugar beet are still too high! DLG-Mitteilungen 98:16, 888-890.

Cracaleanu-M, M. Sirbu, and A. Szekeli, (1995). Economic efficiency of sugar beet mechanized harvesting. Cercetari- Agronomice- inMoldova. Romania, 28:3-4, 19-23.

EL-Sherif, R. R. 1996. A study on harvesting mechanization of Sugar beet- Unpubl. thesis. Fac. of Agric., Kafr El-Sheikh, Tanta Univ., Egypt. 85:90.

Hunt, D. (1983): Farm power and machinery management. 8th Ed. lowa state Univ., Press Ames, USA. Ames, lowa, USA: 364-368.

Ismail, Z. E., Y. M. El -Hadidi. and M.A. EI - Saadany., (1993). The utilization of a developed disc mower to remove the vegetative tops of some tuber crops. Misr. J. Ag. Eng., 10(3): 508 - 524.

Kanafojski, C. Z. and T. Karwowski., (1976). Agricultural machine theory and construction (vol 2: Crop - harvesting machines). Published for the U.S. department of agriculture and the national science foundation, Washington, D.C. P: 830-920 
Khodeir, M.A.A., (2002). Development of a small machine suitable for harvest sugar beet under Egyptian conditions. Ph.D., Thesis. Agric. Mechanization. Dept., Fac. Agric., Kafr El - Sheikh, Tanta Univ.

Mady, M.A., (2001). Mechanization of some operations for sugar beet production. Misr. J. Ag. Eng., 18 (2): 339- 355.

O'Dogherty, M. J. (1986). Journal of Agricultural Engineering Research., 35: 1, 55-66; 11 ref.

Persson, S. (1987). Mechanics of cutting plant material. St. Joseph, Michigan: American Society of Agricultural Engineers. Plinius Gaius, S. AD 77-79. Naturalis Historiæ. In 26. ed.

Raininko, K., (1990). Sweeden sugar beet production, J. of sugar. 1 (29) $32: 62$.

Richey, C.B., P. Jacobson. and C. Hall., (1961). Agricultural engineers'Hand book. McGrow - Hill books Co, INC. New - York. USA. P:270 - 274.

Sharobeem,Y.F; I.M.Abd-El-Tawwab and S. EL-Khawaga (2003). Design and construction of a 3-row lifting machine for sugar beet. Misr. J. Ag. Eng., 20(4): 980-992.

Srivastava, A. k., C. E. Goering., P. R. Rohrbach., (1998). Engineering principles of agricultural machines. ASAE.and Textbook, No (6). Pub. American Society of Agricultural Engineers. P: 45-60

Srivastava, A. K., C. E. Goering and R. P. Rohrbach. (2006). Hay and Forage Harvesting. In Engineering principles of agricultural machines, 325. ed. Anonymous, St. Joseph, Michigan: American Society of Agricultural Engineers. 
Sugar crops council. 2005. Annual report on sugar crops and sugar production in Egypt. (In Arabic). Minster of Agric and land reclamation. P: 18 .

Tayel, S.A., A.A. El-Nakeeb., M.F. Khairy., and N.M. El- Bialee, (2009). Develop and evaluate sugar beet topping unit to suit in small holdings. Misr J. Ag. Eng., 26(1): 44- 55

\section{الملخص العربي}

\section{تظوير وحدة تطويش لبنجر السكر}

يوسف يوسف رمضان* مختار قطب أحمد* أيمن موسى البيهه*

يعاني المزارع المصري من ارتفاع تكلفة حصاد بنجر السكر خاصة عملية النطويش حيث

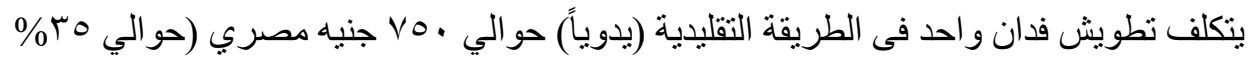

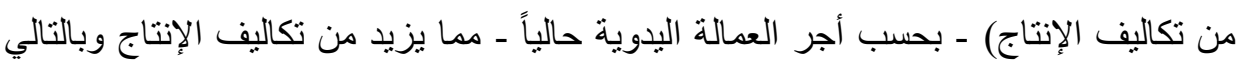
انخفاض الدخل النهائي. كما تعاني معظم آلات الحصاد المتخصصة من انخفاض عدد ساعات التثغيل السنوية وبالتالي تقل الاستفادة منها معظم فصول السنة.

وقد أجريت محاو لات عديدة فى دراسات سابقة للتخلب على هذه المشكلة ولكن النتائج لم تكن على المستوى المطلوب ، فلزم تطوير وحدة بسيطة تقوم بعملية التطويش بكفاءة تقلل من تكاليف الحصاد وكذلك تزيد من إمكانية تشغيل الآلات المتخصصة فى أكثر من غرض على على مستوى

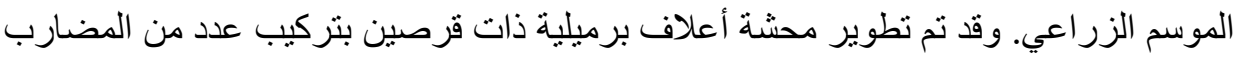
الكاوتش فى اتجاهات و أطو ال و أعداد مختلفة ونم تقييمها تحت سر عات نسبية مختلفة وقد شملت

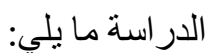
ـ أربع سر عات نسبية [سر عة التقدم للجرار (م/ث)/السر عة المحيطية للأقر اص(م/ث)] , 0.007 ماصن $0.0076,0.0080$ and 0.0085

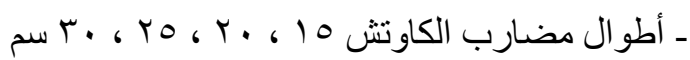

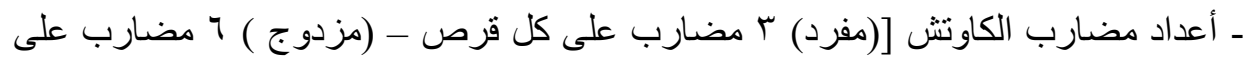

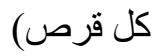
ـ اتجاه مضارب الكاوتش (مواجه يضرب بالوجه العريض Faced - حافى يضرب بالجانب (Edged (الضيق

* معهد بحوث الهندة الزراعية ـ مركز البحوث الزراعية ـ الدقي ـ الجيزة 
وقد تم تحديد نسبة التطويش العلوى والتطويش السفلي والبنجر غير المطوش والبنجر التالف

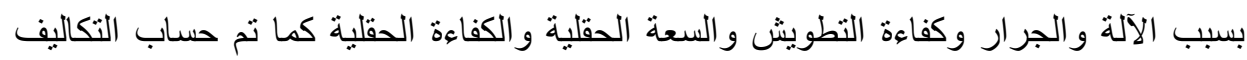
الكلية بالجنيه تحت أنسب ظروف تشغيل لوحدة التطويش. وتم تقييم العوامل السابقة تم تحليل

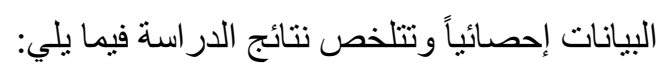

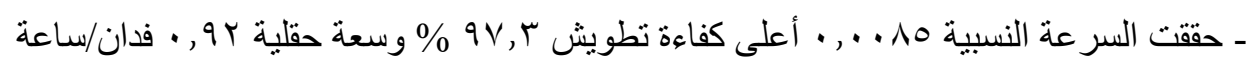

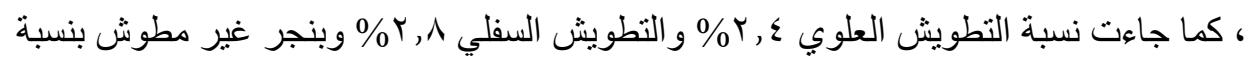

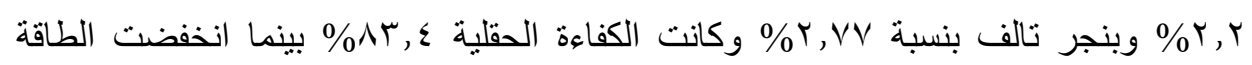

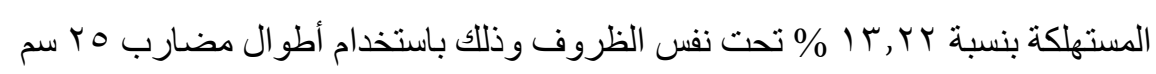
ـ حققت المضارب الكاوتش المزدوجة وفى وضع مواجه (الضرب بالوجه العريض لمضارب الكاوتش1Doubled-Faced-Flail) نتائج أفضل من المضارب المزدوجة وفى وضع حافي

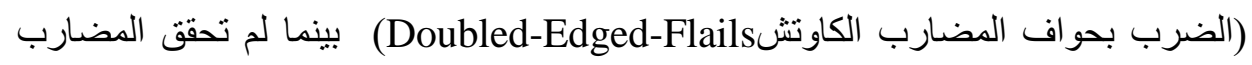
الكاوتش المفردة نتائج مرغوبة ولكن كانت نتائج الوضع المواجه للمضارب المفردة-Solo)

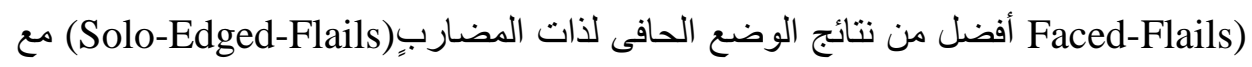
كل القباسات. ـ تم حساب التكاليف الكلية لعلمية التطويش ومقارنتها بالنظام التقليدي (اليدوي) حيث تكلف تطويش فدان واحد بالوحدة المطورة حوالي با 1 جنيه أى انخفضت التكاليف الكلية بنسبة

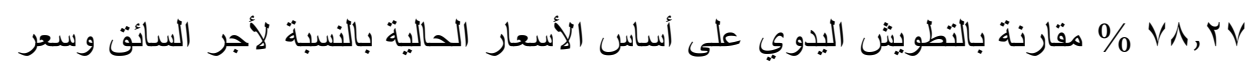

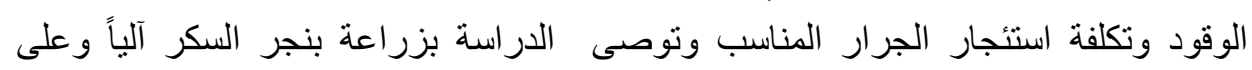

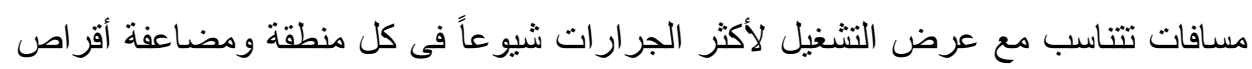
التطويش لزيادة السعة الحقلية وتقليل التكاليف الكلية. 